\title{
Optimal nutrition: calcium, magnesium and phosphorus
}

\author{
Kevin D. Cashman* and Albert Flynn \\ Department of Nutrition, University College, Cork, Republic of Ireland
}

\begin{abstract}
In the past, a major challenge for nutrition research was in defining indicators of nutritional adequacy. More recently, the research base related to the role of nutrition in chronic disease has expanded sufficiently to permit moving beyond deficiency indicators to other indicators with broader functional significance. Thus, nutrition research is faced with the new challenge of defining 'optimal nutrition'. One definition of optimal nutrition with respect to any particular nutrient could be when a functional marker reaches an 'optimal value' or plateau beyond which it is no longer affected by intake or stores of the nutrient. A functional marker of nutrient status could be defined as a physiological or biochemical factor which (1) is related to function or effect of the nutrient in target tissue(s) and (2) is affected by dietary intake or stores of the nutrient (which may include markers of disease risk). Examples of such indicators or markers are those related to risk of chronic diseases such as osteoporosis, CHD, or hypertension. The present review focuses on the concept of optimal nutrition with respect to three nutrients, $\mathrm{Ca}, \mathrm{Mg}$ and $\mathrm{P}$. However, for $\mathrm{P}$ and $\mathrm{Mg}$ there are as yet no functional indicators which respond to dietary intake, and in such cases nutrient requirements are established using more traditional approaches, e.g. balance data. For Ca, there has been interest in using maximal Ca retention, which is based on balance data, bone mass measurements and biomarkers of bone turnover as useful functional indicators of the adequacy of Ca intake.
\end{abstract}

Calcium: Magnesium: Phosphorus: Functional markers

In the not so distant past, a major challenge for nutrition research was in defining indicators of nutritional adequacy. This research was usually limited to classical deficiency states. For example, the dietary allowance for vitamin $\mathrm{C}$ has traditionally been set at a level that will prevent scorbutic symptoms for several weeks on a diet lacking vitamin $\mathrm{C}$ (National Research Council, 1989a).

More recently, the research base related to the role of diet and nutrition in chronic disease has expanded sufficiently to permit moving beyond deficiency indicators to other indicators with broader functional significance. Thus, nutrition research is faced with the new challenge of defining 'optimal nutrition' with respect to the various essential nutrients.

One definition of optimal nutrition with respect to any particular nutrient could be when a functional marker or indicator reaches an 'optimal value' or plateau beyond which it is no longer affected by intake or stores of the nutrient. In this respect, a functional marker of nutrient status could be defined as a physiological and/or biochemical factor which (1) is related to function or effect of the nutrient in target tissue(s) and (2) is affected by dietary intake or stores of the nutrient (which may include markers of disease risk). Examples of such indicators or markers are those related to risk of chronic diseases such as osteoporosis, CHD, or hypertension.

However, for many nutrients there are as yet no functional indicators which respond to dietary intake, and in such cases nutrient requirements are established using more traditional approaches, e.g. balance data.

The present review focuses on the concept of optimal nutrition with respect to three nutrients, $\mathrm{Ca}, \mathrm{Mg}$ and $\mathrm{P}$. While each of these nutrients has very diverse functional and/or structural roles in the body, all three nutrients play a key role in the development and maintenance of bone and other calcified tissues. Indeed, $99 \%$ of the body $\mathrm{Ca}$ (National Research Council, 1989a), $85 \%$ of the body $\mathrm{P}$ (National Research Council, 1989a), and 50-60\% of the body Mg (Elin, 1987) are found in bone and other calcified tissues. However, other biological roles for these nutrients and their possible relevance to human health and to decreasing risk of disease will also be considered.

\footnotetext{
Abbreviations: BMC, bone mineral content; BMD, bone mineral density; Dpyr, deoxypyridinoline; $1,25(\mathrm{OH}) \mathrm{D}_{3}, 1,25$-dihydroxycholecalciferol; Pi, inorganic phosphate; PTH, parathyroid hormone; Pyr, pyridinoline.

*Corresponding author: Dr Kevin Cashman, fax +353 21 270244, email K.Cashman@UCC.ie
} 


\section{Phosphorus}

$\mathrm{P}$ makes up about $6 \cdot 5-11 \mathrm{~g} / \mathrm{kg}$ body weight in adults (Aloia et al. 1984). In the adult body $85 \%$ of the $\mathrm{P}$ is in bone, with the remaining $15 \%$ distributed within the soft tissues (Diem, 1970). Total $\mathrm{P}$ concentration in whole blood is $13 \mathrm{mmol} / \mathrm{l}$, most of which is in the phospholipids of erythrocytes and plasma lipoproteins, with approximately $1 \mathrm{mmol} / \mathrm{l}$ present as inorganic phosphate $(\mathrm{Pi})$. This $\mathrm{Pi}$ component, while constituting only a minute percentage of body $\mathrm{P}$ $(<0.1 \%)$, is of critical importance. In adults this component makes up about $15 \mathrm{mmol}$ in total and is located mainly in the blood and extracellular fluid. It is into this Pi compartment that phosphate is inserted on absorption from the diet and resorption from bone, and from this compartment that most urinary $\mathrm{P}$ and hydroxyapatite mineral $\mathrm{P}$ are derived. This compartment is also the primary source from which the cells of all tissues derive both structural and high-energy phosphate (Institute of Medicine, 1997).

Structurally, P occurs as hydroxyapatite in calcified tissues and as phospholipids, which are a major component of most biological membranes, and as nucleotides and nucleic acids. Other functional roles of $\mathrm{P}$ include: (1) the buffering of acid or alkali excesses, hence helping to maintain normal $\mathrm{pH}$; (2) the temporary storage and transfer of the energy derived from metabolic fuels; (3) by phosphorylation, the activation of many catalytic proteins. Since phosphate is not irreversibly consumed in these processes and can be recycled indefinitely, the actual function of dietary $\mathrm{P}$ is first to support tissue growth (either during individual development or through pregnancy and lactation), and second to replace excretory and dermal losses. In both processes it is necessary to maintain a normal level of Pi in the extracellular fluid, which would otherwise be depleted of its $\mathrm{P}$ by growth and excretion (Institute of Medicine, 1997).

Inadequate $\mathrm{P}$ intake is expressed as hypophosphataemia. Only limited quantities of phosphate are stored within cells, and most tissues depend on extracellular fluid Pi for their metabolic phosphate. When extracellular fluid Pi levels are low, cellular dysfunction follows. At a whole organism level, the effects of hypophosphataemia include anorexia, anaemia, muscle weakness, bone pain, rickets and osteomalacia, general debility, increased susceptibility to infection, paraesthesia, ataxia, confusion, and even death (Lotz et al. 1968). The skeleton will exhibit either rickets in children or osteomalacia in adults. In both groups the disorder consists of a failure to mineralize forming growth plate cartilage or bone matrix, together with impairment of chondroblast and osteoblast function (Lotz et al. 1968). These severe manifestations are usually confined to situations in which extracellular fluid Pi falls below approximately $0.3 \mathrm{mmol} / 1$. $\mathrm{P}$ is so ubiquitous in various foods that near total starvation is required to produce dietary $\mathrm{P}$ deficiency. Re-feeding of energy-depleted individuals, such as those recovering from alcoholic bouts or from diabetic ketoacidosis, either orally or parenterally without attention to supplying Pi can precipitate extreme, even fatal, hypophosphataemia (Knochel, 1977; Bushe, 1986; Dale et al. 1986). Alcontaining antacids, by binding $\mathrm{P}$ in the gut, can, when consumed in high doses, produce hypophosphataemia in their own right, as well as aggravate phosphate deficiency related to other problems (Lotz et al. 1968).

Until recently, dietary $\mathrm{P}$ recommendations have been tied to $\mathrm{Ca}$, usually on an equimass or equimolar basis (see Table 1), and this approach was used in the USA, EU and UK in establishing recommended dietary allowances, population reference intakes, and reference nutrient intakes respectively for $\mathrm{P}$ (National Research Council, 1989a; Department of Health, 1991; Scientific Committee for Food, 1993).

However, the US Food and Nutrition Board recently suggested that a $\mathrm{Ca}: \mathrm{P}$ concept of defining $\mathrm{P}$ requirements is of severely limited value, in that there is little merit to having the ratio 'correct' if the absolute quantities of both nutrients are insufficient to support optimal growth. Furthermore, the intake ratio, by itself, fails to take into account both differing bioavailabilities and physiological adaptive responses of Ca and P (Institute of Medicine, 1997).

Although $\mathrm{P}$ balance might seem to be a logical indicator of nutritional adequacy, it is not an adequate criterion, since an adult can be in zero balance at an intake inadequate to maintain serum $\mathrm{Pi}$ within the normal range (Institute of Medicine, 1997). Even during growth balance will be positive in direct proportion to soft tissue and bony accumulation, but as long as plasma $\mathrm{Pi}$ is high enough the degree of positive balance will be limited either by the genetic programming or by availability of other nutrients (Institute of Medicine, 1997). During senescence, if there is loss of bone or soft tissue mass, $\mathrm{P}$ balance will be negative. However, as long as plasma Pi remains within normal limits, these balances will reflect other changes occurring in the body and will not be an indicator of the adequacy of dietary $\mathrm{P}$ (Institute of Medicine, 1997).

Since $\mathrm{P}$ intake directly affects serum $\mathrm{Pi}$, and because both hypo- and hyperphosphataemia directly result in dysfunction or disease, the US Food and Nutrition Board considered that the most logical indicator of nutritional adequacy of $\mathrm{P}$ intake is serum $\mathrm{Pi}$ (Institute of Medicine, 1997). If serum $\mathrm{Pi}$ is above the lower limits of normal for age, $\mathrm{P}$ intake may be considered adequate to meet cellular and bone formation needs of healthy individuals. However, the relationship between $\mathrm{Pi}$ and $\mathrm{P}$ intake has been clearly established only for adults, and while the adverse effects of low serum Pi are well understood during growth, it is harder to define the critical values for $\mathrm{P}$ intake associated with the normal range of serum $\mathrm{Pi}$ values in infants and children. Thus, estimates of $\mathrm{P}$ requirements were based on a factorial approach in infants, children and adolescents and on serum $\mathrm{Pi}$ in adults (Institute of Medicine, 1997).

Although it is not likely that all levels of serum Pi within the normal range are equally beneficial for cell functioning, insufficient information exists to allow selection of any one value within the population normal range as superior to any other. The recommendation for $\mathrm{P}$ was based on the intake associated with maintenance of serum $\mathrm{Pi}$ at the lower end of the normal range. It was acknowledged that a limitation of this approach lies in the fact that available data on serum Pi apply mostly to the fasting state, whereas it is the integrated $24 \mathrm{~h}$ serum $\mathrm{Pi}$ that is most closely related to absorbed $\mathrm{P}$ intake and that constitutes the actual exposure that the tissues experience (Institute of Medicine, 1997). Moreover, 
Table 1. Recommended phosphorus intakes in the USA and UK*

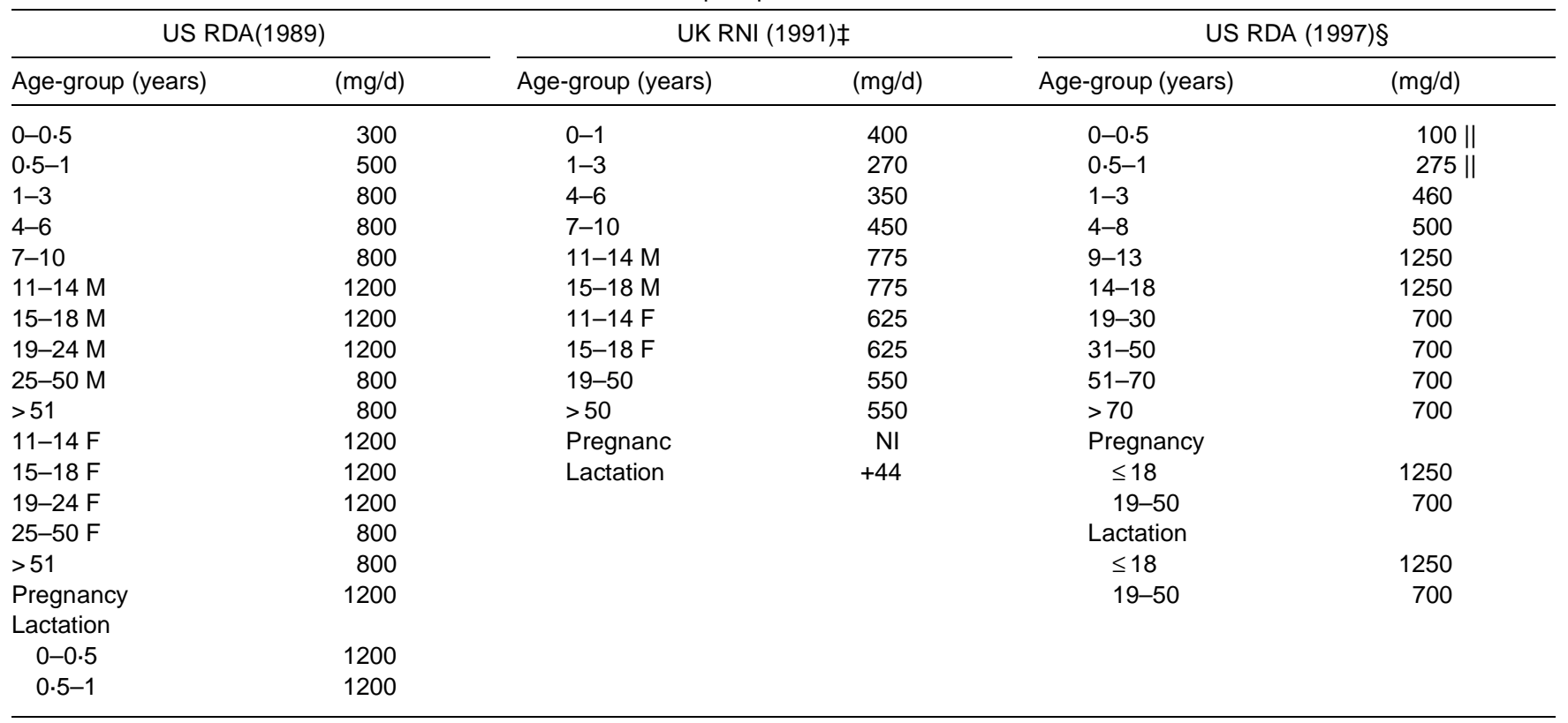

RDA, recommended dietary allowance; RNI, reference nutrient intake; $\mathrm{M}$, requirements for males; $\mathrm{F}$, requirements for females; $\mathrm{NI}$, no increment.

* Estimates of $P$ requirements refer to males and females unless stated otherwise.

† RDA based on Ca:P approach (National Research Council, 1989a).

$\ddagger$ RNI based on Ca:P approach (Department of Health, 1991).

$\S$ RDA based principally on factorial approach and on serum inorganic phosphate levels (Institute of Medicine, 1997).

|| Adequate intake based principally on human milk content (0-0.5 years) or human milk plus solids $(0.5-1.0$ years).

fasting serum $\mathrm{Pi}$ is only weakly correlated with current $\mathrm{P}$ intake (Portale et al. 1987).

\section{Magnesium}

Total body Mg content in the normal adult is approximately $25 \mathrm{~g}(1000 \mathrm{~m} \mathrm{~mol})$, of which 50-6 0\% resides in bone. Onethird of skeletal $\mathrm{Mg}$ is exchangeable, and it is this fraction that may serve as a reservoir for maintaining normal extracellular Mg concentration (Elin, 1987). Extracellular Mg accounts for about $1 \%$ of the total body $\mathrm{Mg}$.

The physiological role of $\mathrm{Mg}$ is principally related to enzyme activity, with over 300 enzyme systems dependent on the presence of this cation (Wacker \& Parisi, 1968a,b,c). All enzyme systems utilizing ATP require $\mathrm{Mg}$ for substrate formation. Intracellular free $\mathrm{Mg}^{2+}$ also acts as an allosteric activator of enzyme action, including critical enzyme systems such as adenylate cyclase ( $E C$ 4.6.1.1), phospholipase $\mathrm{C}$ (EC 3.1.4.3), and $\mathrm{Na}^{+} / \mathrm{K}^{+}$-transporting ATPase (EC 3.6.1.37; Rude, 1998). Transport of other ions such as $\mathrm{K}$ and $\mathrm{Ca}$ across the plasma membrane may also require the presence of $\mathrm{Mg}$ (Rude, 1998). $\mathrm{Mg}$ has been termed 'nature's physiological Ca channel blocker' (Iseri \& French, 1984; White \& Hartzell, 1989). During Mg depletion intracellular $\mathrm{K}$ decreases while $\mathrm{Ca}$ and $\mathrm{Na}$ increase (Iseri \& French, 1984; Whang et al. 1985; White \& Hartzell, 1989; Dorup \& Clausen, 1993). Mg is critical for a number of cellular functions, including oxidative phosphorylation, glycolysis, DNA transcription and protein synthesis (Rude, 1998).

Severe $\mathrm{Mg}$ depletion leads to specific biochemical abnormalities and clinical manifestations that can easily be detected. Hypocalcaemia is a prominent manifestation of moderate to severe $\mathrm{Mg}$ deficiency in human subjects (Rude et al. 1976). $\mathrm{Mg}$ is also important in vitamin $\mathrm{D}$ metabolism and/or action. For example, vitamin D resistance has been reported in $\mathrm{Mg}$-depleted human subjects (Medalle \& Waterhouse, 1973). Neuromuscular hyperexcitability is the initial problem observed in individuals who have or are developing Mg deficiency (Rude \& Singer, 1980).

There is emerging evidence that habitually low intakes of $\mathrm{Mg}$ and resulting abnormal $\mathrm{Mg}$ metabolism are associated with aetiological factors in various metabolic diseases, including cardiovascular disease, hypertension, disorders of skeletal growth and osteoporosis, neuromuscular disorders and diabetes mellitus (Rude, 1998). However, the data currently available are insufficient to permit an estimate of optimal intake of $\mathrm{Mg}$ for health (Institute of Medicine, 1997).

Several potential indicators for estimating daily $\mathrm{Mg}$ requirement have been suggested (Rude, 1998). While Mg is an abundant cation in the body, over $90 \%$ is located either intracellularly or in the skeleton (Elin, 1987). Serum Mg concentration is the most commonly used test to assess $\mathrm{Mg}$ status, but total serum Mg concentration appears to be held within a tight range (17-22 m g/l) (Lowenstein \& Stanton, 1986). A serum concentration of less than $17 \mathrm{mg} / \mathrm{l}$ usually indicates some degree of $\mathrm{Mg}$ depletion (Wong et al. 1983; Quamme, 1993). However, the measurement of serum Mg concentration may not reflect the true total body $\mathrm{Mg}$ content, and low intracellular $\mathrm{Mg}$ has been documented in patients with serum levels above $17 \mathrm{mg} / \mathrm{l}$ (Ryan et al. 1981; Ryzen et al. 1985, 1986; Rude et al. 1991; Nadler et al. 1992; Rude \& Olerich, 1996). Intracellular Mg levels in 
muscle, erythrocytes and lymphocytes, and bone $\mathrm{Mg}$ appear to provide a more accurate assessment of body $\mathrm{Mg}$ status, but such measurements are not readily available for clinical use (Dyckner \& Wester, 1978; Ryan et al. 1981; Ryzen et al. 1985, 1986; Rude et al. 1991). Recently, ion-specific electrodes have become available for determining ionized $\mathrm{Mg}$ in plasma. Early results suggest that this measurement may be a better index of $\mathrm{Mg}$ status than total serum $\mathrm{Mg}$ concentration, but further evaluation is necessary (Rude, 1998). The Mg load, or tolerance, test has been used for many years as a method of assessing $\mathrm{Mg}$ status, but it has been reserved usually for subjects who are deemed to be at risk of $\mathrm{Mg}$ deficiency but have normal serum levels of $\mathrm{Mg}$ (Rude, 1998). This test relies on evaluating the amount of $\mathrm{Mg}$ excreted in urine following an intravenous infusion of $\mathrm{Mg}$. However, the $\mathrm{Mg}$ load test requires normal renal handling of $\mathrm{Mg}$. Age may also be a confounding variable, since older subjects have been reported to retain more $\mathrm{Mg}$ than younger subjects despite comparable dietary Mg intake (Gullestad et al. 1994).

Thus, it is not surprising that the principal method of estimating dietary $\mathrm{Mg}$ requirements in the past has been the dietary balance study (Hunt \& Schofield, 1969; Greger \& Baier, 1983; Mahalko et al. 1983; Schwartz et al. 1984). The US, EU and UK authorities have used Mg balance data in establishing recommended dietary allowances, population reference intakes, and reference nutrient intakes respectively for Mg (National Research Council, 1989a; Department of
Health, 1991; Scientific Committee for Food, 1993; Institute of Medicine, 1997; See Table 2). There are still significant errors associated with the use of balance data for Mg. The US Food and Nutrition Board set out minimum criteria which needed to be fulfilled for balance studies to be included for the development of the new recommended dietary allowances (Institute of Medicine, 1997). These criteria included either an adaptation period of at least $12 \mathrm{~d}$ or a determination of balance while subjects consumed selfselected diets.

\section{Calcium}

$\mathrm{Ca}$, which accounts for $10-20 \mathrm{~g} / \mathrm{kg}$ body weight in adults, is a major component of mineralized tissues, with over $99 \%$ of the total body $\mathrm{Ca}$ found in these tissues. $\mathrm{Ca}$ is required for normal growth and development of the skeleton (National Research Council, 1989a). The remainder is present in blood, extracellular fluid, muscle and other tissues, where it plays a role in mediating vascular contraction and vasodilation, muscle contraction, nerve transmission and glandular secretion (Institute of Medicine, 1997).

The concentration of $\mathrm{Ca}$ in blood is tightly regulated (2.3-2.75 mmol/1; British Nutrition Foundation, 1989). The regulation of plasma Ca concentration is achieved through a complex physiological system comprising the interaction of the calcitropic hormones, such as parathyroid hormone

Table 2. Recommended magnesium intakes in the USA and UK*

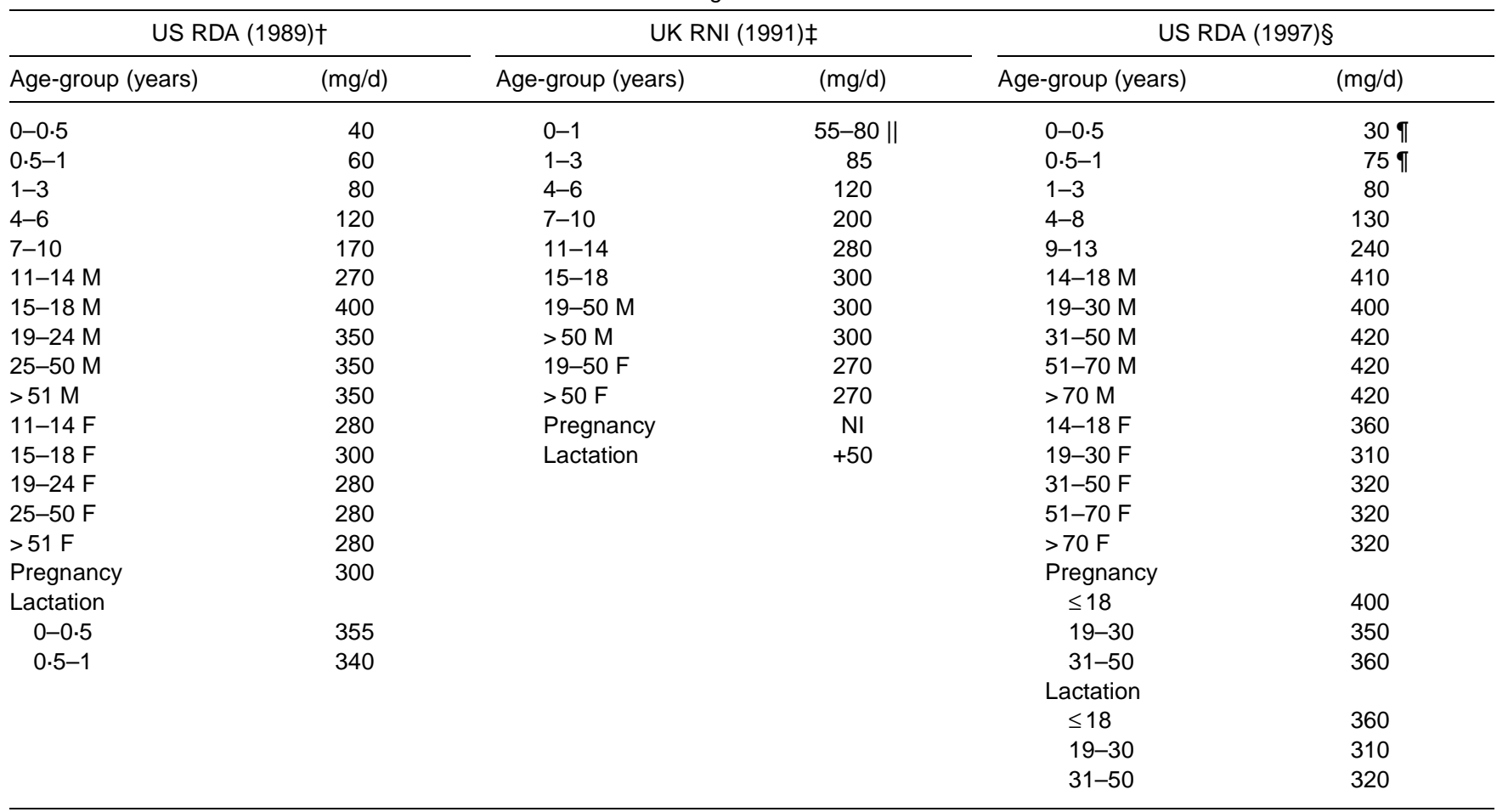

RDA, recommended dietary allowance; RNI, reference nutrient intake; M, requirements for males; F, requirements for females; NI, no increment.

* Estimates of $\mathrm{Mg}$ requirements refer to males and females unless stated otherwise.

† RDA based on factorial approach (National Research Council, 1989a).

¥ RNI based on factorial approach (Department of Health, 1991).

$\S$ RDA based principally on balance data (Institute of Medicine, 1997).

|| $55 \mathrm{mg} \mathrm{Mg} / \mathrm{d}$ for 0-3 months, $60 \mathrm{mg} \mathrm{Mg} / \mathrm{d}$ for 4-6 months, $75 \mathrm{mg} \mathrm{Mg} / \mathrm{d}$ for 7-9 months, $80 \mathrm{mg} \mathrm{Mg} / \mathrm{d}$ for $10-12 \mathrm{months}$.

I Adequate intake based principally on $\mathrm{Mg}$ content of human milk or human milk plus solids. 
(PTH), 1,25-hydroxycholecalciferol $\left(1,25(\mathrm{OH})_{2} \mathrm{D}_{3}\right)$ and calcitonin, with specific target tissues (kidney, bone and intestine) which serve to increase or to decrease the entry of $\mathrm{Ca}$ into the extracellular space. Only in extreme circumstances, such as severe malnutrition or hyperparathyroidism, is the serum ionized $\mathrm{Ca}$ concentration below or above the normal range. The secretion of these hormones is governed wholly or in part by the plasma concentration of ionized $\mathrm{Ca}$, thus forming a negative feedback system. PTH and $1,25(\mathrm{OH})_{2} \mathrm{D}_{3}$ are secreted when plasma Ca is low, while calcitonin is secreted when plasma $\mathrm{Ca}$ is high (British Nutrition Foundation, 1989).

Given the high proportion of body $\mathrm{Ca}$ and the importance of bone as the major reservoir for $\mathrm{Ca}$, development and maintenance of bone is the major determinant of $\mathrm{Ca}$ needs. $\mathrm{Ca}$ requirements vary throughout an individual's life, with greater needs during the periods of rapid growth in childhood and adolescence, during pregnancy and lactation, and in later life.

Chronic Ca deficiency resulting from inadequate intake or poor intestinal absorption gives rise to a PTH-mediated increase in bone resorption and is one of several important causes of reduced bone mass and osteoporosis (National Research Council, 1989b; National Institutes of Health, 1994; Institute of Medicine, 1997). Osteoporosis is characterized by a reduced bone mass (bone mineral density (BMD) more than $2 \cdot 5 \mathrm{SD}$ below the mean for young adult females), increased bone fragility, and increased risk of fracture (World Health Organization, 1994). There has been a large increase in the incidence of osteoporosis in many countries in recent years (Riggs \& Melton, 1995).

The more traditional method of estimating daily $\mathrm{Ca}$ requirements is by a factorial approach, in which an estimate of the average physiological requirement for absorbed $\mathrm{Ca}$ derived from balance data is adjusted for incomplete utilization and variation both in requirements among individuals and in the bioavailability of $\mathrm{Ca}$ among food sources. This approach is subject to considerable uncertainty, as is evident from the wide variation in estimates of daily $\mathrm{Ca}$ requirements made by different expert authorities. For example, the US and UK authorities have established very different recommendations for Ca intake (National Research Council, 1989a; Department of Health, 1991; see Table 3). Much of this divergence arose due to different interpretations of available data, e.g. different absorption efficiencies and estimates of obligatory losses of $\mathrm{Ca}$ were used by the two authorities.

Given the importance of dietary $\mathrm{Ca}$ for bone health there is a clear need for better measures of $\mathrm{Ca}$ adequacy, and recent research suggests that improved assessment of $\mathrm{Ca}$ adequacy may be made using a number of approaches.

\section{Maximal calcium retention}

Recently maximal Ca retention has been considered in the USA as a functional indicator of Ca requirement (Institute of Medicine, 1997; Jackman et al. 1997). To maximize skeletal strength it is important to develop and maintain a Ca reserve in the skeleton. Genetics or heredity to a large extent determines the upper limits of both skeletal size and density (Institute of Medicine, 1997), thus providing a maximum size for the $\mathrm{Ca}$ reserve. An adequate $\mathrm{Ca}$ intake is needed to achieve and preserve these upper limits. In contrast, an inadequate $\mathrm{Ca}$ intake, among other factors, limits the development and preservation of the maximal reserve. It follows that $\mathrm{Ca}$ intake requirement for each age-group is the intake

Table 3. Recommended calcium intakes in the USA and UK*

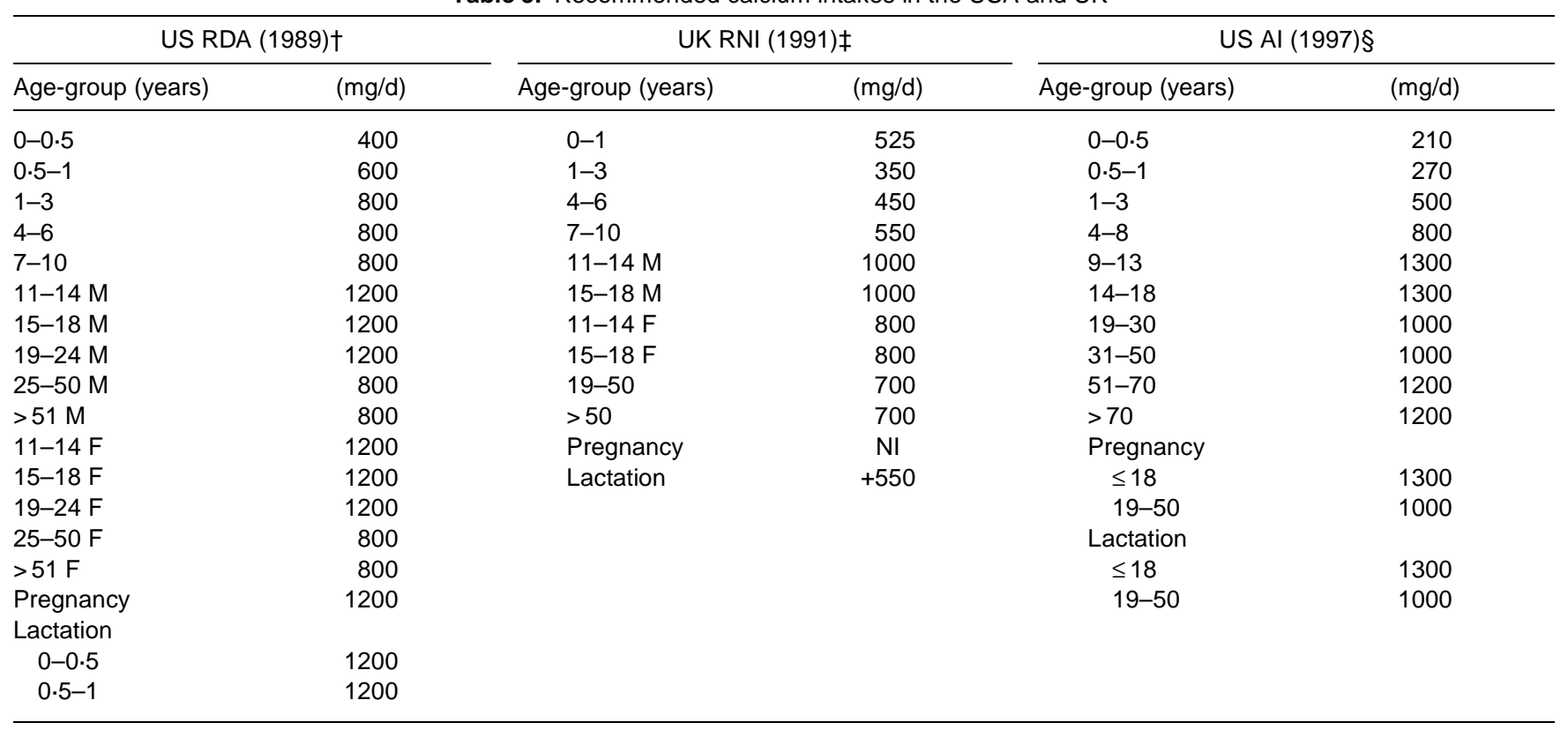

RDA, recommended dietary allowance; $\mathrm{RNI}$, recommended nutrient intake; $\mathrm{Al}$, adequate intake; $\mathrm{M}$, requirements for males; $\mathrm{F}$, requirements for females; $\mathrm{NI}$, no increment.

* Estimates of $\mathrm{Ca}$ requirements refer to males and females unless stated otherwise.

† RDA based on factorial approach (National Research Council, 1989a).

$\ddagger$ RNI based on factorial approach (Department of Health, 1991).

$\S$ Al based principally on maximal Ca retention (Institute of Medicine, 1997). 
needed to achieve maximal $\mathrm{Ca}$ retention in that age-group. Thus, maximal Ca retention is considered by some researchers to be a good functional indicator because (1) its relationship to maximal skeletal $\mathrm{Ca}$ and the associated decrease in the component of fracture risk that can be affected by the diet, (2) there is a plateau intake, at least in children, who are in positive $\mathrm{Ca}$ balance, above which additional $\mathrm{Ca}$ will cause no further gains in retention, and by extension it is the lowest intake at which dietary $\mathrm{Ca}$ dependent bone accretion is maximized (Institute of Medicine, 1997). At intakes above this plateau intake more $\mathrm{Ca}$ is absorbed, but instead of being retained in the skeleton it is excreted in the urine. In the case of older adults, who typically are in negative Ca balance, their plateau intake, as for children, is that above which $\mathrm{Ca}$ retention cannot be further increased with dietary Ca. Although adults may continue to lose bone at the plateau intake (for reasons such as oestrogen deficiency, smoking and sedentary lifestyle etc.), this bone loss is not a consequence of inadequate $\mathrm{Ca}$ intake and cannot be prevented with dietary $\mathrm{Ca}$ (Institute of Medicine, 1997).

Jackman et al. (1997) used Ca intake data from balance studies to develop a non-linear regression model to predict the lowest value of intake at which mean maximal $\mathrm{Ca}$ retention is attained. This approach was used by the US Food and Nutrition Board which established recommendations for daily $\mathrm{Ca}$ intake for different population groups (Institute of Medicine, 1997). A major limitation of the method is the limited balance data available for some population groups. For example, it was not possible to estimate requirements for males and females separately in certain age-groups, and bone mineral mass data was used to estimate the requirements for pregnant or lactating females (Table 3).

\section{Bone mass}

Measures of bone mass may also be used as indicators of $\mathrm{Ca}$ adequacy. These measures include bone mineral content (BMC; which is the amount of mineral at a particular skeletal site such as the femoral neck, lumbar spine or total body) and BMD (which is BMC divided by the area of the scanned region). In addition to their relationship to bone mass and strength, recent studies have indicated that BMD and $\mathrm{BMC}$ are strong predictors of fracture risk (Black et al. 1992; Cummings et al. 1993; Melton et al. 1993). In adults, a decrease of 1SD in femoral neck and lumbar spine BMD is associated with a 2.5-fold and 2-fold increase in risk of hip and vertebral fracture respectively (Cummings et al. 1993).

Cross-sectional studies that relate dietary $\mathrm{Ca}$ intake to BMD are of modest value in establishing the $\mathrm{Ca}$ requirement. Limitations of such studies include: inaccuracies in measuring $\mathrm{Ca}$ intake; $\mathrm{Ca}$ intake at one point in time may not reflect lifetime $\mathrm{Ca}$ intake; bone mass at a single time point results from the lifelong influence of many confounding variables that are not measured (Institute of Medicine, 1997). In contrast, randomized placebo-controlled Ca intervention studies that measure change in BMD provide valuable evidence for the intake requirement for $\mathrm{Ca}$. The findings of many of these controlled $\mathrm{Ca}$ intervention trials have been reviewed by Dawson-Hughes (1991), Institute of Medicine (1997) and Prentice (1997). For example, supplementation studies in post-menopausal women show that an increase in $\mathrm{Ca}$ intake reduces bone loss at the hip (DawsonHughes et al. 1990; Nelson et al. 1991; Reid et al. 1993; Chevalley et al. 1994; Prince et al. 1995), especially for subjects with low habitual Ca intake (Dawson-Hughes et al. 1990). However, increases in Ca intake have little effect on spinal-bone mineral in older women (Nelson et al. 1991; Chevalley et al. 1994; Prince et al. 1995). There have also been a number of published studies of Ca supplementation in children and adolescents that have examined bone mineral status (Johnston et al. 1992; Lloyd et al. 1993; Andon et al. 1994; Lee et al. 1994, 1995; Nowson et al. 1995; Dibba et al. 1998, 1999). The emerging picture is that particularly in prepubertal children, an increased $\mathrm{Ca}$ intake is associated with higher bone mineral status of approximately $1-5 \%$, depending on the skeletal site (for review, see Prentice, 1997). Taken together, the findings of such studies demonstrate that BMD responds to Ca intake and, thus, may be a useful functional marker of $\mathrm{Ca}$ adequacy. A major strength of such longitudinal studies is that the increment in $\mathrm{Ca}$ intake is known. In addition, due to relatively large sample sizes and subject randomization, the influence of confounding factors that might affect bone mass is greatly reduced. Limitations of such studies include: the need for relatively large sample sizes; expense; most of the studies carried out to date have used only one or two dietary levels of Ca (Institute of Medicine, 1997).

An important consideration in the interpretation of longitudinal $\mathrm{Ca}$ intervention studies is the phenomenon of the 'bone remodelling transient', a term used to describe the suppression of bone remodelling which is seen with $\mathrm{Ca}$ supplementation and which results in a one-time initial gain in bone mass over the first 3-12 months after increasing $\mathrm{Ca}$ intake (Frost, 1973). It is thought to reflect completion of osteoblast activity after the inhibition of osteoclastic activity by the increased Ca intake (Slemenda et al. 1997). It is transient to the extent that much if not all the gain in bone mass appears to be sustained only for the duration of $\mathrm{Ca}$ supplementation. This has been observed on follow-up of some Ca supplementation trials in children, which showed that differences in bone mass between subjects and controls disappeared after supplementation ceased (Lee et al. 1996, 1997; Slemenda et al. 1997), although not all studies show this (Bonjour et al. 1997). However, this one-time gain in bone mass resulting from higher $\mathrm{Ca}$ intake may result in a higher peak bone mass in young adults or in a decrease in bone loss in later life, if the higher $\mathrm{Ca}$ intake is maintained (Institute of Medicine, 1997).

Although the available data relating dietary $\mathrm{Ca}$ intake to BMD is still limited, the US Food and Nutrition Board used BMD and BMC data as additional evidence to support the recommendations based on maximal Ca retention (Institute of Medicine, 1997). Notably, where data was sufficient, as was the case for pregnancy and lactation, bone mass measurements, (particularly BMD) were used to establish the estimates of $\mathrm{Ca}$ intake requirements (Institute of Medicine, 1997). 


\section{Biochemical indicators}

While it has been suggested that there is as yet no biochemical indicator that reflects $\mathrm{Ca}$ nutritional status (Institute of Medicine, 1997), recent research suggests that biochemical markers of bone turnover predict bone mass changes and fracture risk, and respond to dietary $\mathrm{Ca}$ intake.

Bone turnover is central to maintenance of the structural function of the skeleton. It is a cyclical process whereby the skeleton undergoes continual renewal by a phased sequence of bone resorption and bone formation, which are coupled, but separated in time (Kanis, 1991). Osteoclasts, the cells responsible for bone resorption, dissolve away a small discrete portion of the surface. The resulting resorption cavity is refilled by the action of osteoblasts, the boneforming cells. Osteoblasts lay down bone matrix (osteoid) which gradually becomes mineralized to form new bone. There is a strict chronological sequence of events, with recruitment of osteoblasts occurring approximately 6-7 weeks after resorption (Eriksen et al. 1984), and with newlyformed bone mineralizing rapidly in the initial stages but more slowly thereafter (Prentice, 1997).

The rate of bone formation and bone resorption, the balance of which ultimately determines bone mass, may be assessed by measurement of biochemical markers (Eastell et al. 1993).

Biochemical markers for monitoring bone turnover all rely on the measurement in serum or urine of enzymes or matrix proteins synthesized by osteoblasts or osteoclasts that spill over into body fluids, or of osteoclast-generated degradation products of the bone matrix itself. Serum levels of skeletal alkaline phosphatase (EC 3.1.3.1) and osteocalcin are currently the most convincing markers of bone formation, while the most useful markers of bone resorption are all products of collagen degradation that currently are best measured in urine (Eyre, 1996). These newer markers have been reported to have improved specificity and responsiveness to bone cell activity over more traditional markers, such as urinary hydroxyproline and serum total alkaline phosphatase (Delmas, 1992; Eyre, 1992; Eriksen et al. 1995), which have a number of well-documented limitations (Robins, 1982; Delmas, 1992).

Produced primarily by osteoblasts, most of the newlysynthesized osteocalcin is immediately bound to the bone mineral, with only a proportion being secreted directly into blood (Gundberg et al. 1983). It is measured in serum by an immunoassay, and appears to be a good marker of the rate of bone formation (Eyre, 1996). Total alkaline phosphatase activity in serum is still the most used index of bone formation in clinical use, especially in conditions where large increases in bone turnover occur, such as Paget's disease (Robins \& New, 1997). However, it is less useful for detecting more subtle changes in bone metabolism, and bone-specific bone alkaline phosphatase measured in serum using specific monoclonal antibodies is now widely used as a biochemical marker of bone formation (Eyre, 1996).

It has been consistently shown that the most specific and sensitive markers of bone resorption are urinary markers of bone resorption (Eyre, 1996). Urinary levels of the pyridinium cross-links of collagen, pyridinoline (Pyr) and deoxypyridinoline (Dpyr), have been the most studied markers of bone resorption in the last decade (Eyre, 1996). Pyr and Dpyr function as mature cross-links in collagen of most connective tissues other than skin. Since bone is such a major reservoir of type I collagen in the body and turns over faster than most major connective tissues, Pyr and Dpyr cross-links in urine are primarily derived from bone resorption (Eyre, 1996). This conclusion is supported by the molar ratio Pyr: Dpyr in urine which is usually similar to that of bone (between 3 and 4), compared with most nonosseous connective tissue in which Dpyr is usually present at less than $10 \%$ of the content of Pyr (Eyre, 1992). Theoretically, therefore, urinary Dpyr is more specific than Pyr as a marker of bone resorption. These complex amino acids appear not to be metabolized after tissue collagen is degraded, and are excreted in urine where they can be measured by HPLC using their natural fluorescence for detection (Eyre et al. 1984). In addition, determination of free cross-link content in urine has been facilitated by the development of direct immunoassays which implement monoclonal antibody technology (Robins et al. 1994).

Recently, a number of other urinary assays have been developed, based not on the cross-links themselves but on peptides derived from amino acid sequences in the vicinity of the cross-linking regions of collagen type I (Robins \& New, 1997). These assays include those that use monoclonal antibodies recognizing peptides comprising part of either the $\mathrm{N}$ - or C-terminal telopeptides, known generically as the urine-based NTx assay (Hanson et al. 1992) and the serumbased CTx assay (Risteli et al. 1993) respectively.

Recently, it has been recognized that an increased rate of bone turnover in adults may be a risk factor for fracture (Riggs et al. 1996), because it exacerbates bone loss (Hansen et al. 1991). Conversely, a reduced rate of bone turnover may lower risk of fracture by maximizing development of peak bone mass in young adults (Slemenda et al. 1997) and slowing the rate of bone loss in later life (Riggs et al. 1996). High rates of bone turnover are also associated with a disruption of the trabecular network, leading to a loss of connectivity which is not necessarily reflected in a decrease of bone mass (Parfitt, 1984).

The availability of these newer markers of bone turnover has widened the scope for investigation of subtle changes in bone metabolism such as those brought about by dietary influences. Although the available data are still limited, they do indicate that these biochemical markers of $\mathrm{Ca}$ and bone metabolism are influenced by dietary $\mathrm{Ca}$ intake and, thus, might be of value in defining optimal $\mathrm{Ca}$ intakes. For example, Riggs et al. (1998) carried out a 4-year randomized controlled $\mathrm{Ca}$ intervention trial $(1600 \mathrm{mg} \mathrm{Ca} / \mathrm{d})$ in postmenopausal women who had a mean usual $\mathrm{Ca}$ intake of $714 \mathrm{mg} / \mathrm{d}$. Ca supplementation significantly reduced serum osteocalcin and urinary Pyr levels as well as bone loss at the femur and total body. Similar findings of reduced bone turnover have been reported in a number of other Ca supplementation studies conducted over periods of 2-4 years in peri- or post-menopausal women (Elders et al. 1994; Prince et al. 1995; McKane et al. 1996). Such observations are not limited to older age-groups, but have been made also in children and adolescents. For example, Johnston et al. (1992) showed that Ca supplementation $(1000 \mathrm{mg} / \mathrm{d})$ for 3 years significantly reduced serum levels of osteocalcin in 
prepubertal children with a mean usual $\mathrm{Ca}$ intake of $900 \mathrm{mg} / \mathrm{d}$. The reductions in serum osteocalcin levels with Ca supplementation were accompanied by greater increases in BMD. Similarly, Dibba et al. (1998) showed that Ca supplementation $(714 \mathrm{mg} / \mathrm{d})$ for 12 months of 10 -year-old rural Gambian children accustomed to a low $\mathrm{Ca}$ intake $(300-400 \mathrm{mg} / \mathrm{d})$ significantly lowered serum levels of osteocalcin and increased bone mineral status $(P \leq 0.001$; Dibba et al. 1999) over that time. However, Cadogan et al. (1997) did not observe any change in serum osteocalcin or a number of other indicators of bone turnover in adolescent girls whose mean usual Ca intake of $746 \mathrm{mg} / \mathrm{d}$ was supplemented with an additional $568 \mathrm{ml}$ milk/d for 18 months, although BMC and BMD were reported to increase.

While it takes at least 1 year to obtain a measurable response of bone mass to changes in Ca intake, responses of biochemical indicators of bone metabolism occur over a shorter period. Indicators of bone resorption respond within hours to days, while indicators of bone formation respond over months. There are a number of short-term studies which show a response of biochemical indicators of bone resorption to changes in dietary Ca. For example, Ginty et al. (1998) examined the effect of increased Ca intake on biochemical markers of bone turnover in healthy young adults (mean age 23 years) over a 2 -week period. The results showed that supplementation of the usual diet $(22 \mathrm{mmol}$ $(882 \mathrm{mg}) \mathrm{Ca} / \mathrm{d})$ with additional $\mathrm{Ca}(20 \mathrm{mmol}(800 \mathrm{mg}) / \mathrm{d})$ for a 2-week period resulted in a significant reduction in the urinary excretion of Pyr and Dpyr, indicating a reduction in the rate of bone resorption. Similar findings have been reported in a number of other short-term studies which examined the influence of $\mathrm{Ca}$ supplementation on biochemical markers of bone turnover (Horowitz et al. 1984, 1994; Need et al. 1987; Shapses et al. 1995; Rubinacci et al. 1996; Scopacasa et al. 1998).

Evidence from longer-term Ca intervention studies (1-4 years; Johnston et al. 1992; Elders et al. 1994; Prince et al. 1995; McKane et al. 1996; Dibba et al. 1998, 1999; Riggs et al. 1998) indicates that the changes in bone metabolism observed in short-term studies are sustained while the $\mathrm{Ca}$ intervention is maintained, and thus such short-term studies may be useful indicators of $\mathrm{Ca}$ adequacy. However, such short-term studies should be of a minimum of 2 weeks duration, as Dawson-Hughes et al. (1993) has shown that Ca-regulating hormone levels and fractional $\mathrm{Ca}$ retention require up to 2 weeks to stabilize after a change in dietary $\mathrm{Ca}$ intake. Thus, once sufficient time is allowed for adaptation to new dietary $\mathrm{Ca}$ intake, studies which use biochemical markers of bone turnover may be useful in predicting the long-term effects of $\mathrm{Ca}$ on bone turnover and bone mass, and thus may be of use in defining optimal Ca intakes.

The effect of Ca supplementation on bone turnover in the previously mentioned studies is due to the increased $\mathrm{Ca}$ intake raising plasma $\mathrm{Ca}$, leading to a suppression of plasma PTH and consequently the renal production of $1,25(\mathrm{OH})_{2} \mathrm{D}_{3}$. Reduced serum levels of PTH and $1,25(\mathrm{OH})_{2} \mathrm{D}_{3}$ reduce the stimulus for osteoclastic bone resorption (Rubinacci et al. 1996).

Evidence for this PTH-mediated mechanism is provided by the significant reduction in serum PTH in response to $\mathrm{Ca}$ supplementation observed in a number of these studies
(McKane et al. 1996; Riggs et al. 1998). For example, McKane et al. (1996) showed that serum PTH was reduced by $40 \%$ and urinary Dpyr by $35 \%$ in post-menopausal women who were maintained on a supplemented $\mathrm{Ca}$ intake $(60 \cdot 2 \mathrm{mmol}(2414 \mathrm{mg}) / \mathrm{d})$ for up to 3 years compared with age-matched subjects on their usual Ca intakes $(20.4 \mathrm{mmol}$ $(815 \mathrm{mg}) / \mathrm{d})$. Riggs et al. (1998) showed that serum PTH and bone loss were reduced in post-menopausal women supplemented with an additional $1600 \mathrm{mg} \mathrm{Ca} / \mathrm{d}$ for 4 years compared with unsupplemented age-matched subjects whose habitual Ca intake was $714 \mathrm{mg} / \mathrm{d}$. Indeed, the responsiveness of serum PTH to dietary Ca suggests that it too could be considered as a potential indicator of $\mathrm{Ca}$ adequacy.

\section{Conclusions}

At present, serum Pi seems to be the best marker for estimating adequacy of $\mathrm{P}$ intake in adults. However, the model that relates dietary intake to serum Pi requires further investigation in infants, children and adolescents. There are, as yet, no functional indicators of $\mathrm{P}$ status. The dietary balance approach is considered to be the best available method for estimating $\mathrm{Mg}$ requirements. While the $\mathrm{Mg}$ tolerance test is a useful indicator of $\mathrm{Mg}$ status in the clinical setting, intracellular $\mathrm{Mg}$ content (e.g. erythrocyte or lymphocyte $\mathrm{Mg}$ ) is a more practical approach to assessing status. The lack of functional markers of $\mathrm{Mg}$ status is a significant disadvantage for studies relating Mg intake or status to health outcomes such as hypertension, cardiovascular disease and osteoporosis. Maximal $\mathrm{Ca}$ retention (which is based on balance data) and bone mass measurements are useful functional indicators of the adequacy of $\mathrm{Ca}$ intake and have been used by the US Food and Nutrition Board in estimating the 'adequate intake' of $\mathrm{Ca}$ for different population groups (Institute of Medicine, 1997). Biochemical markers of bone turnover have been shown to respond to dietary $\mathrm{Ca}$ in short-term (weeks) and long-term (years) studies and are predictive of changes in bone mass and fracture risk. Thus, the response of these markers to $\mathrm{Ca}$ intake may be useful for estimating dietary $\mathrm{Ca}$ requirements.

\section{References}

Aloia JF, Vaswani AN, Yeh JK, Ellis K \& Cohn SH (1984) Total body phosphorus in postmenopausal women. Mineral and Electrolyte Metabolism 10, 73-76.

Andon MB, Lloyd T \& Matkovic V (1994) Supplementation trials with calcium citrate malate: Evidence in favour of increasing the calcium RDA during childhood and adolescence. Journal of Nutrition 124, 1412S-1417S.

Black DM, Cummings SR, Genant HK, Nevitt MC, Palermo L \& Browner W (1992) Axial and appendicular bone density predict fractures in older women. Journal of Bone and Mineral Research 7, 633-638.

Bonjour JP, Carrie AL, Ferrari S, Clavien H, Slosman D \& Theintz G (1997) Calcium-enriched foods and bone mass growth in prepubertal girls: a randomised, double-blind, placebocontrolled trial. Journal of Clinical Investigation 99, 1287-1294.

British Nutrition Foundation (1989) Calcium. London: British Nutrition Foundation.

Bushe CJ (1986) Profound hypophosphataemia in patients collapsing after a 'fun run'. British Medical Journal 292, 898-899. 
Cadogan J, Eastell R, Jones N \& Barker ME (1997) Milk intake and bone mineral acquisition in adolescent girls: randomised, controlled intervention trial. British Medical Journal 315, 12551260.

Chevalley T, Rizzoli R, Nydegger V, Slosman D, Rapin C-H, Michel J, Vasey H \& Bonjour J-P (1994) Effects of calcium supplements on femoral bone mineral density and vertebral fracture rate in vitamin D replete elderly patients. Osteoporosis International 4, 245-252.

Cummings SR, Black DM, Nevitt MC, Browner W, Cauley J, Ensrud K, Genant HK, Palermo L, Scott J \& Vogt TM (1993) Bone density at various sites for prediction of hip fracture. The Study of Osteoporotic Fractures Research Group. Lancet 341, $72-75$.

Dale G, Fleetwood JA, Inkster JS \& Sainsbury JR (1986) Profound hypophosphataemia in patients collapsing after a 'fun run'. British Medical Journal 292, 447-448.

Dawson-Hughes B (1991) Calcium supplementation and bone loss :a review of controlled clinical trials. American Journal of Clinical Nutrition 54, 274S-280S.

Dawson-Hughes B, Dallal GE, Krall EA, Sadowski L, Sahyoun N \& Tannenbaum S (1990) A controlled trial of the effect of calcium supplementation on bone density in post-menopausal women. New England Journal of Medicine 323, 878-883.

Dawson-Hughes B, Harris S, Kramich C, Dallal G \& Rasmussen HM (1993) Calcium retention and hormone levels in black and white women on high- and low-calcium diets. Journal of Bone and Mineral Research 8, 779-787.

Delmas PD (1992) Clinical use of biochemical markers of bone remodelling in osteoporosis. Bone 13, 517-521.

Department of Health (1991) Dietary Reference Values for Food Energy and Nutrients for the United Kingdom. Report on Health and Social Subjects no. 41. London: H.M. Stationery Office.

Dibba B, Prentice A, Poskitt EME \& Cole TJ (1998) Calcium supplementation increases the bone mineral status of Gambian children. Proceedings of the Nutrition Society 57, 73A.

Dibba B, Prentice A, Stirling D \& Poskitt EME (1999) Effect of calcium supplementation on plasma osteocalcin concentration of Gambian children. Proceedings of the Nutrition Society 58, 61A.

Diem K (1970) Documenta Geigy. Ardsley, NY: Geigy Pharmaceuticals.

Dorup I \& Clausen T (1993) Correlation between magnesium and potassium contents in muscle: Role of $\mathrm{Na}\left({ }^{+}\right)-\mathrm{K}^{+}$pump. American Journal of Physiology 264, C457-C463.

Dyckner T \& Wester PO (1978) The relationship between extraand intracellular electrolytes in patients with hypokalemia and/or diuretic treatment. Acta Medica Scandinavica 204, 269-282.

Eastell R, Robins SP, Colwell T, Assiri AM, Riggs BL \& Russell RG (1993) Evaluation of bone turnover in type I osteoporosis using biochemical markers specific for both bone formation and bone resorption. Osteoporosis International 3, 255-260.

Elders PJM, Lips P, Netelenbos JC, Van Ginkel FC, Khoe E, van der Vijgh WJF \& van der Stelt PF (1994) Long-term effect of calcium supplementation on bone loss in perimenopausal women. Journal of Bone and Mineral Research 9, 938-970.

Elin RJ (1987) Assessment of magnesium status. Clinical Chemistry 33, 1965-1970.

Eriksen EF, Brixen K \& Charles P (1995) New markers of bone metabolism: Clinical use in metabolic bone disease. European Journal of Endocrinology 132, 251-263.

Eriksen EF, Gundersen HJG, Melsen F, Mosekilde L (1984) Reconstruction of the formative site in iliac trabecular bone in 20 normal individuals employing a kinetic model for matrix and mineral apposition. Metabolic Bone Disease Related Research $\mathbf{5}$, 243-252.

Eyre D (1996) Biochemical markers of bone turnover. In Primer on the Metabolic Bone Diseases and Disorders of Mineral Metabo- lism, 3rd ed., pp. 114-118 [MJ Favus, editor]. New York: Lippincott-Raven.

Eyre DR (1992) New biomarkers of bone resorption. Journal of Clinical Endocrinology and Metabolism 74, 470A-470C.

Eyre DR, Paz MA \& Gallop PM (1984) Cross-linking in collagen and elastin. Annual Reviews in Biochemistry 53, 717-748.

Frost HM (1973) The origin and nature of transients in human bone remodeling dynamics. In Clinical Aspects of Metabolic Bone Disease, pp. 124-137 [B Frame, AM Parfitt and H Duncan, editors]. Amsterdam: Excerpta Medica.

Ginty F, Flynn A \& Cashman KD (1998) The effect of short-term calcium supplementation on biochemical markers of bone metabolism in healthy young adults. British Journal of Nutrition 80, 437-443.

Greger JL \& Baier MJ (1983) Effect of dietary aluminum on mineral metabolism of adult males. American Journal of Clinical Nutrition 38, 411-419.

Gullestad L, Nes M, Ronneberg R, Midtvedt K, Falch D \& Kjekshsu J (1994) Magnesium status in healthy free-living elderly Norwegians. Journal of the American College of Nutrition 13, 45-50.

Gundberg CM, Lian JB, Gallop PM \& Steinberg JJ (1983) Urinary $\gamma$-carboxyglutamic acid and serum osteocalcin as bone markers: Studies in osteoporosis and Paget's disease. Journal of Clinical Endocrinology and Metabolism 57, 1221-1225.

Hansen MA, Overgaard K, Riis BJ \& Christiansen C (1991) Role of peak bone mass and bone loss in postmenopausal osteoporosis: 12 year study. British Medical Journal 303, 961-964.

Hanson D, Weis M, Bollen A, Maslan S, Singer F \& Eyre D (1992) A specific immunoassay for monitoring human bone resorption: quantitation of type I collagen cross-linked $\mathrm{N}$-telopeptides in urine. Journal of Bone and Mineral Research 7, 1251-1258.

Horowitz M, Need AG, Philcox JC \& Nordin BEC (1984) Effect of calcium supplementation on urinary hydroxyproline in osteoporotic postmenopausal women. American Journal of Clinical Nutrition 39, 857-859.

Horowitz M, Wishart JM, Goh D, Morris HA, Need AG \& Nordin BEC (1994) Oral calcium suppresses biochemical markers of bone resorption in normal men. American Journal of Clinical Nutrition 60, 965-968.

Hunt MS \& Schofield FA (1969) Magnesium balance and protein intake level in adult human female. American Journal of Clinical Nutrition 22, 367-373.

Institute of Medicine (1997) Dietary Reference Intakes: Calcium, Magnesium, Phophorus, Vitamin D, and Fluoride. Washington, DC: National Academy Press.

Iseri LT \& French JH (1984) Magnesium: Nature's physiologic calcium blocker. American Heart Journal 108, 188-193.

Jackman LA, Millane SS, Martin BR, Wood OB, McCabe GP, Peacock M \& Weaver CM (1997) Calcium retention in relation to calcium intake and postmenarcheal age in adolescent females. American Journal of Clinical Nutrition 66, 327-333.

Johnston CC Jr, Miller JZ, Slemenda CW, Reister TK, Hui S, Christian JC \& Peacock M (1992) Calcium supplementation and increases in bone mineral density in children. New England Journal of Medicine 327, 82-87.

Kanis JA (1991) Calcium requirements for optimal skeletal health in women. Calcified Tissue International 49, S33-S41.

Knochel JP (1977) The pathophysiology and clinical characteristics of severe hypophosphataemia. Archives of Internal Medicine 313, 447-449.

Lee WTK, Leung SSF, Cheng JCY, Wang SH, Xu YC \& Zeng W-P (1995) Effects of calcium supplementation and subsequentwi thdrawal on bone acquisition of Chinese children. Proceedings of the 7th Asian Congress of Nutrition, F-61-03, p. 343. Beijing: Chinese Nutrition Society. 
Lee WTK, Leung SSF, Leung DMY \& Cheng JCY (1996) A follow-up study on the effects of calcium-supplement withdrawal and puberty on bone acquisition of children. American Journal of Clinical Nutrition 64, 71-77.

Lee WTK, Leug SSF, Leung DMY, Wang SH, Xu YC, Zeng WP \& Chang JC (1997) Bone mineral acquisition in low calcium intake children following the withdrawal of calcium supplement. Acta Paediatrica 86, 570-576.

Lee WTK, Leung SSF, Wang SH, Xu YC, Zeng W-P, Lau J, Oppenheimer SJ \& Cheng JCY (1994) Double-blind, controlled calcium supplementation and bone mineral accretion in children accustomed to a low-calcium diet. American Journal of Clinical Nutrition 60, 744-750.

Lloyd TM, Andon MB, Rollings N, Martel JK, Landis JR, Demers LM, Eggli DF, Keisekhorst K \& Kulin HE (1993) Calcium supplementation and bone mineral density in adolescent girls. Journal of the American Medical Association 270, 841-844.

Lotz M, Zisman E \& Bartter FC (1968) Evidence of phosphorusdepletion syndrome in man. New England Journal of Medicine 278, 409-415.

Lowenstein FW \& Stanton MF (1986) Serum magnesium levels in the United States, 1971-1974. Journal of the American College of Nutrition 5, 399-414.

Mahalko JR, Sandstead HH, Johnson LK \& Milne DB (1983) Effect of a moderate increase in dietary protein on the retention and excretion of $\mathrm{Ca}, \mathrm{Cu}, \mathrm{Fe}, \mathrm{Mg}, \mathrm{P}$ and $\mathrm{Zn}$ by adult males. American Journal of Clinical Nutrition 37, 8-14.

McKane WR, Khosla S, Egan KS, Robins SP, Burritt MF \& Riggs BL (1996) Role of calcium intake in modulating age-related increases in parathyroid function and bone resorption. Journal of Clinical Endocrinology and Metabolism 81, 1699-1703.

Medalle R \& Waterhouse C (1973) A magnesium-deficient patient presenting with hypocalcemia and hyperphosphatemia. Annals of Internal Medicine 79, 76-79.

Melton LJ III, Atkinson EJ, O'Fallon WM, Wahner HW \& Riggs BL (1993) Long-term fracture prediction by bone mineral assessed at different skeletal sites. Journal of Bone and Mineral Research 8, 1227-1233.

Nadler JL, Malayan S, Luong H, Shaw S, Natarajan RD \& Rude RK (1992) Intracellular free magnesium deficiency plays a key role in increased platelet reactivity in type II diabetes mellitus. Diabetes Care 15, 835-841.

National Institutes of Health (1994) Optimal Calcium Intake. NIH Consensus Statement 12:4. Bethesda, MD: National Institutes of Health.

National Research Council (1989a) Recommended Dietary Allowances, 10th ed. Washington, DC: National Academy Press.

National Research Council (1989b) Diet and Health: Implications for Reducing Chronic Disease Risk. Washington, DC: National Academy Press.

Need AG, Horowitz M, Philcox JC \& Nordin BEC (1987) Biochemical effects of a calcium supplement in osteoporotic postmenopausal women with normal absorption and malabsorption of calcium. Mineral and Electrolyte Metabolism 13, 112-116.

Nelson ME, Fisher EC, Dilmanian TA, Dallal GE \& Evans WJ (1991) A 1-y walking program and increased dietary calcium in post-menopausal women: effects in bone. American Journal of Clinical Nutrition 53, 1304-1311.

Nowson CA, Green RM, Guest CS, Larkins RG, Sherwin AJ, Kaymakci B, Smid M, Young D, Hopper JL \& Wark JD (1995) The effect of calcium supplementation on bone mass in adolescent female twins. In Nutritional Aspects of Osteoporosis '94, pp. 169-175 [P Burckhardt and RP Heaney, editors]. Rome: Ares-Serono Symposia Publications.
Parfitt AM (1984) Age-related structural changes in intrabecular and cortical bone: Cellular mechanisms and biomechanical consequences. Calcified Tissue International 36, S123-S128.

Portale AA, Halloran BP \& Morris RC Jr (1987) Dietary intake of phosphorus modulates the circadian rhythm in serum concentration of phosphorus. Implications for the renal production of 1,25-dihydroxyvitamin D. Journal of Clinical Investigations 80, 1147-1154.

Prentice A (1997) Is nutrition important in osteoporosis? Proceedings of the Nutrition Society 56, 357-367.

Prince R, Devine A, Dick I, Criddle A, Kerr D, Kent N, Price R \& Randell A (1995) The effects of calcium supplementation (milk or tablets) and exercise on bone density in postmenopausal women. Journal of Bone and Mineral Research 10, 1068-1075.

Quamme GA (1993) Laboratory evaluation of magnesium status. Renal function and free intracellular magnesium concentration. Clinical Laboratory Medicine 13, 209-223.

Reid IR, Ames RW, Evans MC, Gamble GD \& Sharpe SJ (1993) Effect of calcium supplementation on bone loss in postmenopausal women. New England Journal of Medicine 328, 460-464.

Riggs BL \& Melton LJ III (1995) The worldwide problem of osteoporosis: insights afforded by epidemiology. Bone 17, 505S-511S.

Riggs BL, Melton LJ III \& O'Fallon WM (1996) Drug therapy for vertebral fractures in osteoporosis: Evidence that decreases in bone turnover and increases in bone mass both determine antifracture efficacy. Bone 18, 197S-201S.

Riggs L, O'Fallon M, Muhs J, O'Connor MK, Kumar R \& Melton L III (1998) Long-term effects of calcium supplementation on serum parathyroid hormone level, bone turnover, and bone loss in elderly women. Journal of Bone and Mineral Research 13, 168-174.

Risteli L, Risteli J \& Moniz C (1993) Measuring collagen degradation. European Journal of Clinical Investigation 23, 339-340.

Robins SP (1982) An enzyme-linked immunoassay for the collagen cross-link pyridinoline. Biochemical Journal 207, 617-620.

Robins SP \& New SA (1997) Markers of bone turnover in relation to bone health. Proceedings of the Nutrition Society 56, 903-914.

Robins SP, Woitge H, Hesley R, Ju J, Seyedin S \& Seibel MJ (1994) Direct enzyme-linked immunoassay for urinary deoxypyridinoline as a specific marker for measuring bone resorption. Journal of Bone and Mineral Research 9, 1643-1649.

Rubinacci A, Divieti P, Polo RM, Zampino M, Resimini G \& Tenni R (1996) Effect of an oral calcium load on urinary markers of collagen breakdown. Journal of Endocrinological Investigation 19, 719-726.

Rude RK (1998) Magnesium deficiency: a cause of heterogenous disease in humans. Journal of Bone and Mineral Research 13, 749-758.

Rude RK, Oldham SB \& Singer FR (1976) Functional hypoparathyroidism and parathyroid hormone end-organ resistance in human magnesium deficiency. Clinical Endocrinology 5, 209-244.

Rude RK \& Olerich M (1996) Magnesium deficiency: Possible role in osteoporosis associated with gluten-sensitive enteropathy. Osteoporosis International 6, 453-461.

Rude RK \& Singer FR (1980) Magnesium deficiency and excess. Annual Reviews of Medicine 32, 245-259.

Rude RK, Stephen A \& Nadler J (1991) Determination of red blood cell intracellular free magnesium by nuclear resonance as an assessment of magnesium depletion. Magnesium and Trace Elements 10, 117-121.

Ryan MP, Ryan MF \& Counihan TB (1981) The effect of diuretics on lymphocyte magnesium and potassium. Acta Medica Scandinavica 647, 153-161. 
Ryzen E, Elbaum N, Singer FR \& Rude RK (1985) Parental magnesium tolerance testing in the evaluation of magnesium deficiency. Magnesium 4, 137-147.

Ryzen E, Elkayam U \& Rude RK (1986) Low blood mononuclear cell magnesium in intensive cardiac care unit patients. American Heart Journal 111, 475-480.

Schwartz R, Spencer H \& Welsh JJ (1984) Magnesium absorption in human subjects from leafy vegetables, intrinsically labeled with stable ${ }^{26} \mathrm{Mg}$. American Journal of Clinical Nutrition 39, 571-576.

Scientific Committee for Food (1993) Reports of the Scientific Committee for Food series no 31. Nutrient and Energy Intakes of the European Community. Luxembourg: Commission of European Communities.

Scopacasa F, Horowitz M, Wishart JM, Need AG, Morris HA, Wittert G \& Nordin BE (1998) Calcium supplementation suppresses bone resorption in early postmenopausal women. Calcified Tissue International 62, 8-12.

Shapses SA, Robins SP, Schwartz EI \& Chowdhury H (1995) Short-term changes in calcium but not protein intake alter the rate of bone resorption in healthy subjects as assessed by urinary pyridinium cross-link excretion. Journal of Nutrition 125, 2814-2821.
Slemenda CW, Peacock M, Hui S, Zhou L \& Johnston CC (1997) Reduced rates of skeletal remodeling are associated with increased peak bone mineral density during the development of peak skeletal mass. Journal of Bone and Mineral Research 12, 676-682.

Wacker WE \& Parisi AF (1968a) Magnesium metabolism. New England Journal of Medicine 45, 658-663.

Wacker WE \& Parisi AF (1968b) Magnesium metabolism. New England Journal of Medicine 45, 712-717.

Wacker WE \& Parisi AF (1968c) Magnesium metabolism. New England Journal of Medicine 45, 772-776.

Whang R, Flink EB, Dyckner T, Wester PO, Aikawa JK \& Ryan MP (1985) Magnesium depletion as a cause of refactory potassium repletion. Archives of Internal Medicine 145, 1686-1689.

White RE \& Hartzell HC (1989) Magnesium ions in cardiac function. Biochemistry and Pharmacology 38, 859-867.

World Health Organization (1994) Assessment of Fracture Risk and its Application to Screening for Postmenopausal Osteoporosis. Technical Report Series no. 843. Geneva: WHO.

Wong ET, Rude RK, Singer FR \& Shaw ST (1983) A high prevalence of hypomagnesemia and hypermagnesemia in hospitalized patients. American Journal of Clinical Pathology 79, 348-352. 